\title{
BIOSYNTHESIS OF $\triangle$-AMINOLEVULINATE IN GREENING BARLEY LEAVES: GLUTAMATE 1-SEMIALDEHYDE AMINOTRANSFERASE
}

by

\author{
C. GAMINI KANNANGARA and SIMON P. GOUGH
}

Department of Physiology, Carlsberg Laboratory, Gamle Carlsberg Vej 10, DK-2500 Copenhagen, Valby

Keywords: Chloroplast, etioplast, glutamate substrate, synthetic substrate

\begin{abstract}
L-Glutamate-1-semialdehyde was synthesized by catalytic hydrogenation of N-carbobenzoxy-L-glutamyl-1chloride-5-benzyl ester. Soluble protein extracts of chloroplasts isolated from greening barley leaves enzymically converted L-glutamate-1-semialdehyde to $\delta$-aminolevulinate. The enzyme was partially purified by gel filtration on a Biogel column excluding proteins larger than 500,000 daltons. The enzyme had a broad pH optimum around 8.0 and required no specific cofactors for activity. Aminooxyacetate $(20 \mathrm{~mm})$, cycloserine $(20 \mathrm{~mm})$, p-chloromercuribenzoate $(0.1 \mathrm{mM})$, glyoxylate $(20 \mathrm{mM})$ and pyridoxal phosphate $(5 \mathrm{mM})$ inhibited $\delta$-aminolevulinate formation from L-glutamate-1-semialdehyde. However, $\beta$ - hydroxyglutamate $(1 \mathrm{mM})$ a potent inhibitor of Lglutamate- $\mathrm{U}-{ }^{14} \mathrm{C}$ conversion to $\delta$-aminolevulinate, had no effect on L-glutamate-1-semialdehyde aminotransferase. The aminotransferase activity was eluted from the Biogel column together with the enzyme activity that converted $\mathrm{L}$-glutamate- $\mathrm{U}-{ }^{14} \mathrm{C}$ into $\delta$-aminolevulinate. Soluble proteins prepared from etiolated plastids and mature chloroplasts of barley had a low specific activity of L-glutamate-1-semialdehyde aminotransferase compared to soluble proteins from greening plastids. It is proposed that L-glutamate-1semialdehyde aminotransferase catalyses a part reaction in the conversion of L-glutamate to $\delta$-aminolevulinate in greening barley plastids.
\end{abstract}

\section{INTRODUCTION}

Previous studies have demonstrated that chloroplasts and cell free systems from greening leaves convert ${ }^{14} \mathrm{C}$ labelled L-glutamate and/ or $\alpha$-ketoglutarate into $\delta$-aminolevulinate $(4,5$, $6,8) . \Delta$-aminolevulinate formation from glutamate in stroma preparations of greening barley plastids has been shown to require ATP, NADPH and $\mathrm{Mg}^{2+}$. The biosynthesis of $\delta$ aminolevulinate from glutamate is therefore considered to proceed according to Figure 1 in- volving the following three steps: (I) glutamate is phosphorylated with ATP in the presence of $\mathrm{Mg}^{2+}$, (II) the glutamate-1-phosphate is reduced by NADPH to glutamate-1-semialdehyde and (III) the aldehyde is transaminated to $\delta$ aminolevulinate. In this paper we report a synthesis of glutamate-1-semialdehyde, the postulated precursor of $\delta$-aminolevulinate. Greening barley is shown to have an enzyme which catalyses the conversion of glutamate-1semialdehyde to $\delta$-aminolevulinate. 


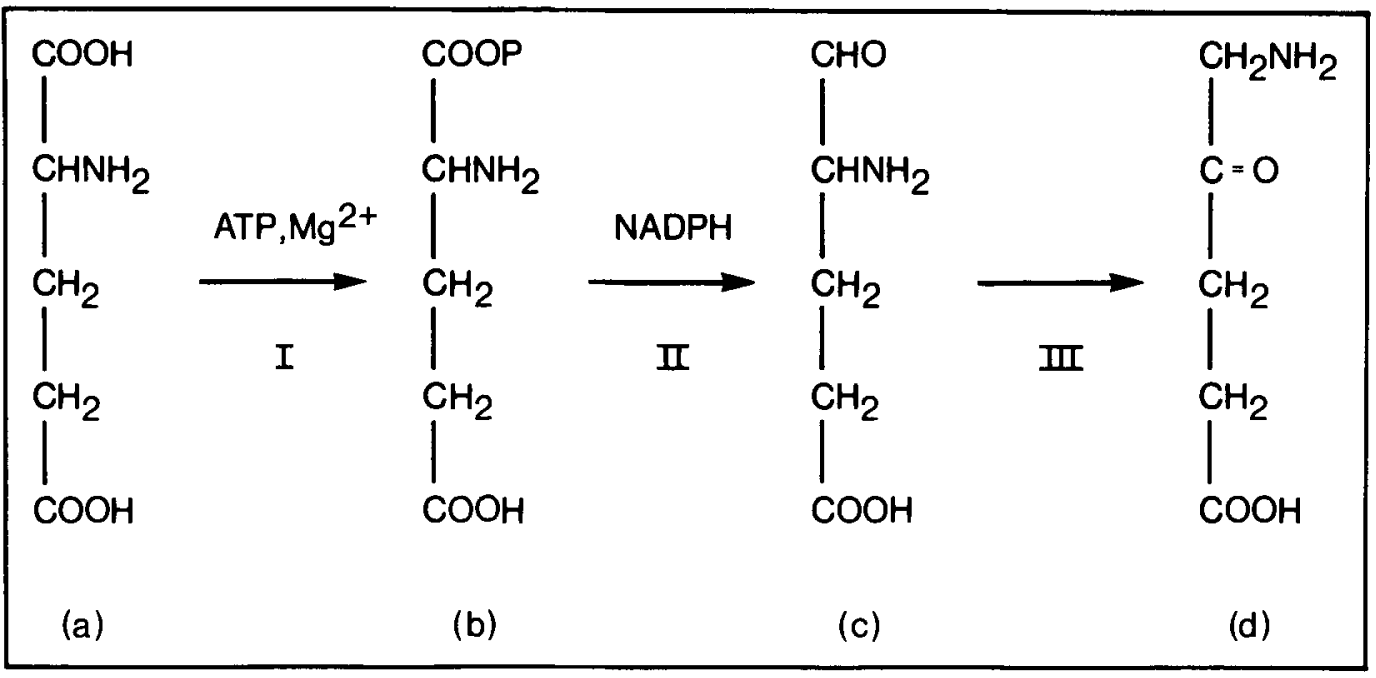

Figure 1. Proposed scheme for $\delta$-aminolevulinate biosynthesis from L-glutamate in greening barley plastids. a) glutamate, b) glutamate-1-phosphate, c) glutamate 1-semialdehyde, d) $\delta$-aminolevulinate. The reaction $I$ is catalysed by a kinase and the reaction II by a dehydrogenase. Glutamate-1-semialdehyde aminotransferase catalyses the reaction III.

\section{MATERIALS AND METHODS}

\subsection{Plant material}

Seeds of barley (Hordeum vulgare L. cv. Svalöf's Bonus) were germinated and grown on moist vermiculite at $21^{\circ} \mathrm{C}$ for 6 days either in complete darkness or in light. Greening seedlings were obtained by illuminating the dark grown seedlings for 6 hours with "Osram Fluora" fluorescent light.

\subsection{Chemicals}

N-Carbobenzoxy-L-glutamate- $\gamma$-benzyl ester was obtained from Bachem Inc., Marina del Rey, California, U.S.A. L-Glutamate-U-14 C of specific activity $290 \mathrm{mCi} / \mathrm{mmole}$ was obtained from Radiochemical Centre, Amersham. DL- $\beta$ hydroxyglutamate was supplied by ICN Pharmaceuticals, Cleveland, Ohio, U.S.A.

\subsection{Plastid isolation}

Leaves were harvested, cooled on ice, and homogenized in a precooled homogenizer fitted with razor blades (9). Approximately $160 \mathrm{~g}$ fresh weight of pre-cooled leaves were homogenized with $400 \mathrm{ml}$ of ice cold medium containing 0.6 M-glycerol, $0.1 \mathrm{M}$-Tricine, $3 \mathrm{mM}-\mathrm{Ca}\left(\mathrm{NO}_{3}\right)_{2}$ and the $\mathrm{pH}$ adjusted to 7.9 with $\mathrm{NaOH}$. The homogenate was squeezed through a single layer of nylon gauze $(31 \mu$ mesh) and filtered through another layer of similar nylon gauze. The filtrate was centrifuged for 5 minutes at 0 $4^{\circ} \mathrm{C}$ in a Sorval RC 2B centrifuge at $3000 \mathrm{rpm}$ using a GSA rotor $(1500 \times \mathrm{g})$. The plastid pellet was gently suspended in approximately $40 \mathrm{ml}$ of ice cold suspension medium containing $0.3 \mathrm{M}$ glycerol, $0.1 \mathrm{M}$-tricine, and $1 \mathrm{~mm}$-dithiothreitol. The $\mathrm{pH}$ of the suspension medium was adjusted with $\mathrm{NaOH}$ to 7.9. Plastids were again pelleted by centrifugation for 5 minutes at $3500 \mathrm{rpm}$ in the Sorval centrifuge using a SS34 rotor (1400x $\mathrm{g}$ ). The final plastid pellet was resuspended in a small volume (ca. 10 to $15 \mathrm{ml}$ ) of medium containing $1 \mathrm{mM}-\mathrm{MgCl}_{2}$ and the other components of the suspension medium. Uniform suspension of plastids was achieved employing a Potter Elvehjem homogenizer.

\subsection{Extraction of soluble protein from isolated plastids and purification of enzyme activity}

Plastid suspensions were passed through an ice cold French pressure cell at 16000 p.s.i. and centrifuged for 1 hour at $50000 \mathrm{rpm}$ in a Beckman L5/75 ultracentrifuge at $0-4^{\circ} \mathrm{C}$ using a 
Ti 50 rotor. The clear supernatant contained the soluble proteins of the plastids and was used either directly in enzyme assays or after partial purification using a Biogel A 0.5 column. A column (2.5 times $85 \mathrm{~cm}$ ) was loaded with 10 to $15 \mathrm{ml}$ of protein solution containing 3 to $6 \mathrm{mg}$ protein per $\mathrm{ml}$ and eluted with a medium containing $0.3 \mathrm{M}$-glycerol, $0.1 \mathrm{M}$-Tricine, $1 \mathrm{mM}$ dithiothreitol, $1 \mathrm{~mm}-\mathrm{MgCl}_{2}$ and adjusted to $\mathrm{pH}$ 7.9 with $\mathrm{NaOH}$. The eluate was scanned for ultraviolet light absorption using a LKB uvicord II and $8 \mathrm{ml}$ fractions were collected.

\subsection{Synthesis of L-glutamate 1-semialdehyde}

N-Carbobenzoxy L-glutamate $\gamma$-benzyl ester $(500 \mathrm{mg})$ was dissolved in a minimal volume $(4 \mathrm{ml})$ of dry ether in a $50 \mathrm{ml}$ centrifuge tube and cooled on ice. Phosphorus pentachloride

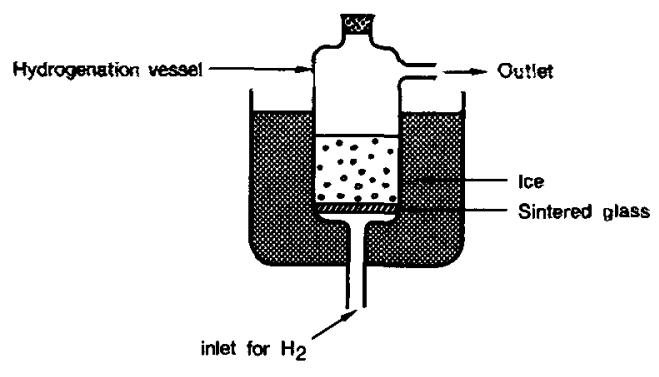

Figure 2. Hydrogenation set-up.

(500 mg) was added to this solution and gently shaken. Within 5 to 10 minutes the formation of a white crystalline mass of the acid chloride takes place and the reaction is allowed to run to completion by keeping the tubes for an additional 30 minutes on ice. The crystals were washed three times with $25 \mathrm{ml}$ aliquots of hex-

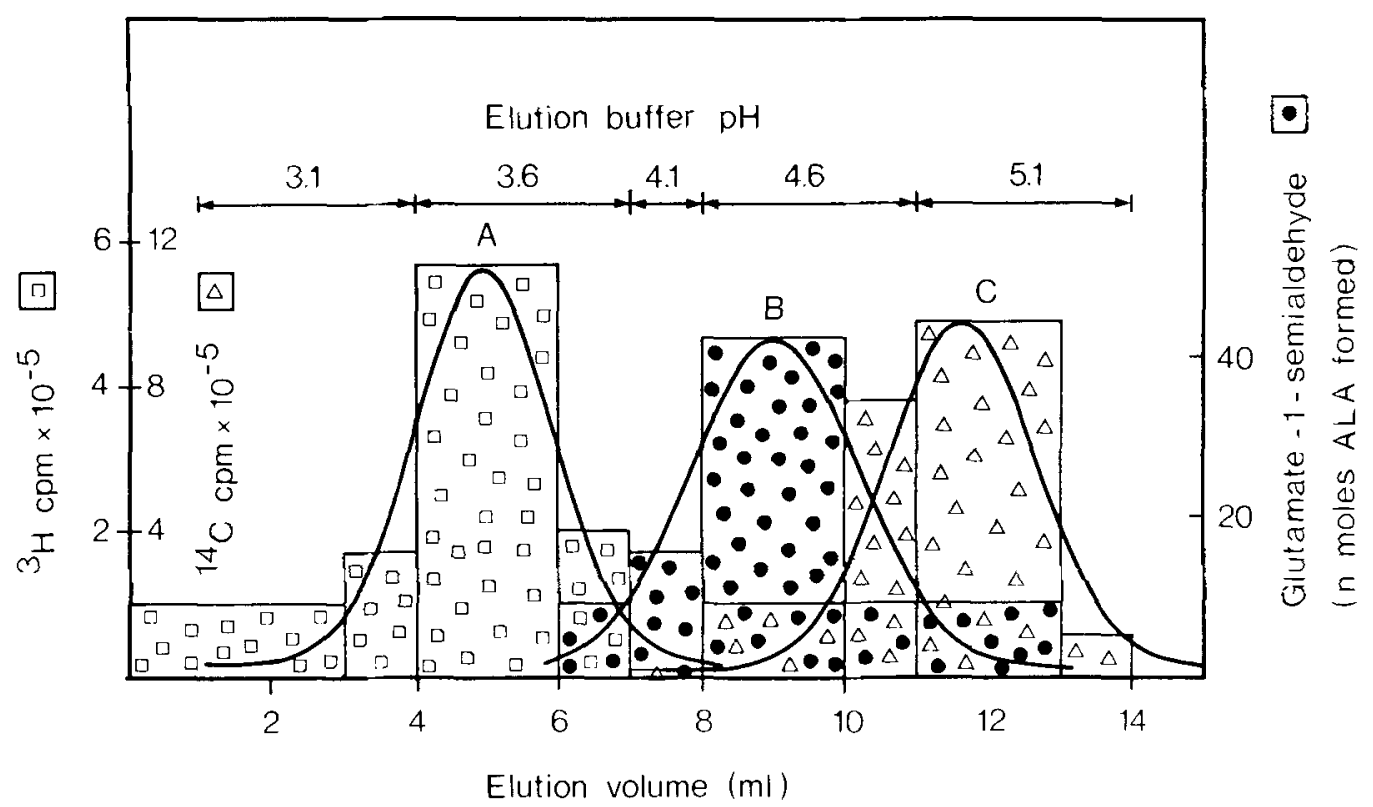

Figure 3. Purification of glutamate-1-semialdehyde from glutamate and $\delta$-aminolevulinic acid. Elution profiles are A. glutamate, B. glutamate-1-semialdehyde, C. $\delta$-aminolevulinate. The normal distribution curves were matched by eye to the histograms.

A pre-equilibrated Dowex $50 \times 8$ column $(2 \times 0.6 \mathrm{~cm})$ was loaded with $1.2 \mathrm{ml}$ of a mixture containing Lglutamate-4- ${ }^{3} \mathrm{H}, \delta$-aminolevulinate- $5 \cdot{ }^{14} \mathrm{C}$ and glutamate-1-semialdehyde preparation. The $\mathrm{pH}$ of the mixture was 1.6. The column was washed stepwise with sodium citrate buffers in the following order: $3 \mathrm{ml}$ of buffer at pH 3.1 . 2 plus $1 \mathrm{ml}$ buffer at $\mathrm{pH} 3.6,1 \mathrm{ml}$ of buffer at $\mathrm{pH} 4.1,2$ plus $1 \mathrm{ml}$ of buffer at $\mathrm{pH} 4.6$ and $3 \mathrm{ml}$ of buffer at $\mathrm{pH} 5.1$. All citrate buffers were $0.2 \mathrm{~N}$ for $\mathrm{Na}^{+}$. The washings were collected separately and the ${ }^{3} \mathrm{H}$ and ${ }^{14} \mathrm{C}$ counts determined. Glutamate-1-semialdehyde was assayed enzymically as given in 2.6. ALA $=\delta$-aminolevulinate. 
ane and finally dissolved in $40 \mathrm{ml}$ of dry ether. The ether solution was placed in the hydrogenation vessel (Figure 2) with $500 \mathrm{mg}$ of freshly prepared dry palladium black and $10 \mu \mathrm{l}$ of quinoline poison (cf. 2.7.). The mixture was cooled on ice. The ice cold mixture was bubbled with $\mathrm{N}_{2}$ for 1 to 2 minutes and then vigorously with $\mathrm{H}_{2}$. Liberation of $\mathrm{HCl}$ during hydrogenation was monitored by holding a filter paper moistened with ammonia to the outlet of the hydrogenation vessel. The formation of aldehyde was also followed by spot tests on filter paper using Schiff's reagent. Hydrogenation was allowed to proceed at $0^{\circ} \mathrm{C}$ until no further $\mathrm{HCl}$ was liberated. Ether was then separated from the palladium black and the latter was extracted three times with $5 \mathrm{ml}$ aliquots of water. The ether fraction was extracted twice with $3 \mathrm{ml}$ aliquots of water. The aqueous extracts contained the glutamate-1-semialdehyde and were pooled and purified by ion exchange chromatography. The aqueous extract was acidic ( $\mathrm{pH}$ between 1 and 2) and was found to contain two major ninhydrin positive substances when analysed on an amino acid analyser. One of the peaks corresponded to glutamate and the other was eluted close to the $\delta$-aminolevulinate standard. The yield of semialdehyde was $11 \%$, determined as given in 2.5.2.

\subsubsection{Purification of glutamate-1-semialdehyde}

Preparations were absorbed on a Dowex 50X8 (200-400 mesh) ion exchange column $(2 \times 0.6 \mathrm{~cm})$ pre-equilibrated with sodium citrate buffer having a $\mathrm{pH}$ of 3.1. The column was then washed stepwise with different quantities of sodium citrate buffers of increasing $\mathrm{pH}$ as follows: $3 \mathrm{ml}$ at $\mathrm{pH} \mathrm{3.1,2}$ plus $1 \mathrm{ml}$ at $\mathrm{pH} 3.6,1$ $\mathrm{ml}$ at $\mathrm{pH} 4.1,2$ plus $1 \mathrm{ml}$ at $\mathrm{pH} 4.6$ and $3 \mathrm{ml}$ at pH 5.1. All sodium citrate buffers were prepared by adjusting $0.2 \mathrm{M}-\mathrm{NaOH}$ with solid citric acid. As evident from the results in Figure 3 this procedure separates glutamate-1semialdehyde from glutamate and $\delta$-aminolevulinate. Glutamate-1-semialdehyde migrated with an $\mathrm{R}_{\mathrm{f}}$ of 0.27 in descending chromatograms on Whatmann $3 \mathrm{MM}$ paper developed with $N$-butanol:acetic acid:water $(25: 4: 10 \mathrm{v} / \mathrm{v} / \mathrm{v})$ and was well separated from glutamate $\left(\mathrm{R}_{\mathrm{f}} 0.12\right)$ and $\delta$-aminolevulinate $\left(R_{\mathrm{f}} 0.35\right)$. Glutamate-1semialdehyde on chromatograms was identified by spraying with ninhydrin (yellow spot), spraying with Schiff's reagent (characteristic aldehyde colour), and spraying with dinitrophenylhydrazine reagent (yellow spot), as well as its ability to be converted into $\delta$-aminolevulinate on incubation with enzyme.

\subsubsection{Estimation of glutamate-1- semialdehyde concentration}

The amount of glutamate-1-semialdehyde in purified preparations was determined by titration for carbonyl groups (14).

\subsection{Glutamate-1-semialdehyde aminotransferase assay}

The enzyme assay was performed in $15 \mathrm{ml}$ tubes. The incubation mixture contained in a total volume of $1 \mathrm{ml}$ the following: $0.3 \mathrm{M}$ glycerol, $0.1 \mathrm{M}$-Tricine- $\mathrm{NaOH}, \quad 0.25 \mathrm{~mm}-$ dithiothreitol, $1 \mathrm{mM}$-glutamate-1-semialdehyde and 50 to $100 \mu \mathrm{g}$ enzyme protein. The $\mathrm{pH}$ of the incubation mixture was 7.9 . The mixtures were incubated for 15 minutes at $22^{\circ} \mathrm{C}$. Reactions were stopped by placing the tubes in ice and addition of $50 \mu \mathrm{l}$ of $70 \%$ perchloric acid. Precipitated protein was centrifuged off and $50 \mu$ of $5 \mathrm{~N}-\mathrm{KOH}$ added. The precipitate of $\mathrm{KClO}_{4}$ was removed by centrifugation. $\triangle$-aminolevulinate present in the supernatant was condensed with ethyl acetoacetate and the pyrrole formed was estimated. These procedures have been described before (11).

\subsection{Other methods}

Protein was measured according to LowRY et al. (10). Optical density was measured using a Zeiss PMQ 3 spectrophotometer. Assays for Lglutamate- $U-{ }^{14} \mathrm{C}$ incorporation into $\delta$-aminolevulinate and determinations of radioactivity were performed as described previously (4). Palladium black was prepared according to the method described in (12) and dried by washing with acetone and dry ether. Quinoline poison was prepared according to the method described in (7). 
Table I

Cofactor requirement for glutamate l-semialdehyde aminotransferase.

\begin{tabular}{lc}
\hline Experiment & $\begin{array}{c}\delta \text {-Aminolevulinate formed } \\
\text { n moles }\end{array}$ \\
\hline 1. Control & 7.53 \\
$2 .+0.5 \mathrm{mM}-\mathrm{ATP}$ & 6.50 \\
$3 .+0.5 \mathrm{mM}-\mathrm{ATP}+0.25 \mathrm{mM}-\mathrm{NADPH}$ & 6.74 \\
$4 .+0.5 \mathrm{mM}-\mathrm{ATP}+0.25 \mathrm{mM}-\mathrm{NADPH}+25 \mathrm{mM}-\mathrm{MgCl}_{2}$ & 6.00 \\
$5 .+5 \mathrm{mM}-\mathrm{L}$-glutamate & 7.24 \\
$6 .+5 \mathrm{mM}-\mathrm{L}$-phenylalanine & 7.57 \\
$7 .+5 \mathrm{mM}-\mathrm{L}-$ alanine & 7.20 \\
$8 .+5 \mathrm{mM}$-aspartate & 7.32 \\
9. - Enzyme & 0 \\
10. Boiled enzyme & 0 \\
\hline
\end{tabular}

Incubations were carried out in a total volume of $1 \mathrm{ml}$ in $15 \mathrm{ml}$ tubes for 15 minutes at $22^{\circ} \mathrm{C}$. The control incubation mixture in experiment 1 contained $89 \mu \mathrm{g}$ partially purified enzyme, $1 \mathrm{mM}$-glutamate-1-semialdehyde, $0.25 \mathrm{~mm}$ dithiothreitol, $0.3 \mathrm{M}$-glycerol and $0.1 \mathrm{M}$-Tricine- $\mathrm{NaOH}$ at $\mathrm{pH}$ 7.9. In experiment 10 the enzyme was placed in a boiling water bath for 5 minutes and cooled on ice before adding the incubation mixture.

\section{RESULTS}

\subsection{Properties of glutamate-1-semialdehyde aminotransferase}

Table I illustrates the cofactor requirement for $\delta$-aminolevulinate synthesis from glutamate-1-semialdehyde. None of the cofactors which stimulate the conversion of $\mathrm{L}$ glutamate- $U-{ }^{14} \mathrm{C}$ to $\delta$-aminolevulinate $(5)$ are required for glutamate-1-semialdehyde aminotransferase activity. Glutamate and aspartate function as amino donors of several plant transamination reactions. Phenylalanine and alanine were reported as amino group donors in a dioxovalerate transaminase reaction (3). All four amino acids were without effect on glutamate1 -semialdehyde aminotransferase activity. This makes it likely that the enzyme catalyses a transfer of the amino group at the C-2 position of the semialdehyde molecule to the $\mathrm{C}-1$ position. The enzyme has a broad $\mathrm{pH}$ optimum around 8.0 (Figure 4 ) and within the range of the three temperatures tested $\delta$ aminolevulinate formation was highest at $30^{\circ} \mathrm{C}$ (Table II). Figure 5 illustrates the effect of increasing amounts of substrate in the incubation mixture. Glutamate-1-semialdehyde concen-

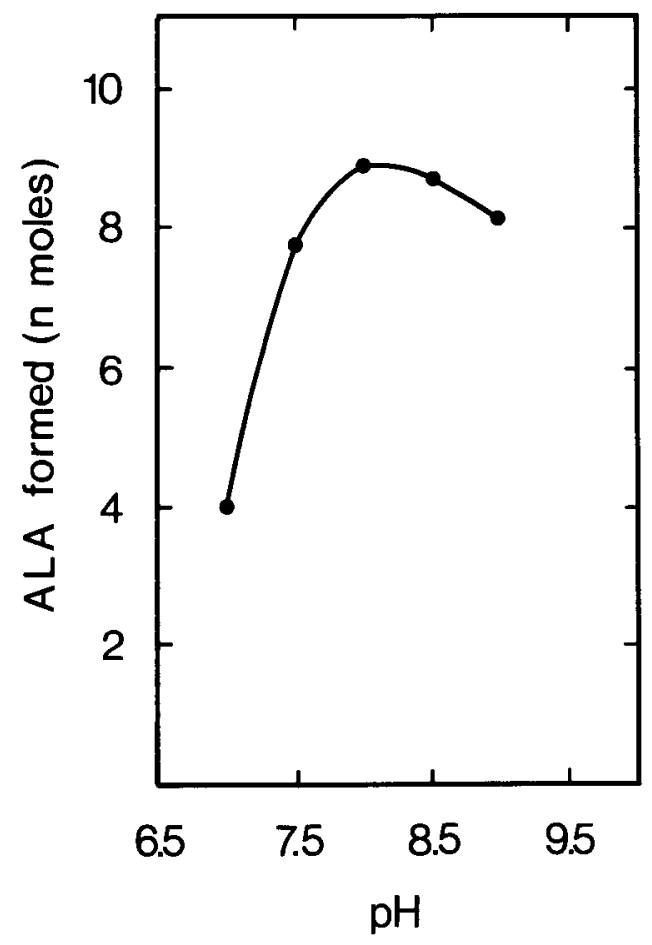

Figure 4. The effect of $\mathrm{pH}$ on glutamate-1semialdehyde aminotransferase. $0.1 \mathrm{M}$-tricine- $\mathrm{NaOH}$ buffers were used and the assays were performed as given under Table I. ALA $=\boldsymbol{\delta}$-aminolevulinate. 
Table II

The effect of temperature on glutamate 1-semialdehyde aminotransferase.

Incubation temperature $\delta$-Aminolevulinate formed ${ }^{\circ} \mathrm{C}$ n moles

\begin{tabular}{rr}
14 & 4.06 \\
22 & 7.53 \\
30 & 9.85 \\
\hline
\end{tabular}

Assays were performed under the conditions given for experiment 1 in Table I except for variations in temperature.

trations below $2 \mathrm{mM}$ stimulated $\delta$-aminolevulinate formation, whereas higher concentrations inhibited the glutamate-1-semialdehyde aminotransferase activity. These data result in a $\mathrm{K}_{\mathrm{m}}$ value for the substrate of about $0.4 \mathrm{~mm}$. Under the assay conditions described in section $2.6 \delta$-aminolevulinate formation from glutamate-1-semialdehyde is approximately linear up to 30 minutes (Figure 6).

\subsection{Inhibitors of glutamate-1-semialdehyde aminotransferase}

Inhibitor studies with plastids isolated from greening barley leaves have shown that biosynthesis of $\delta$-aminolevulinate from $\mathrm{L}$ -

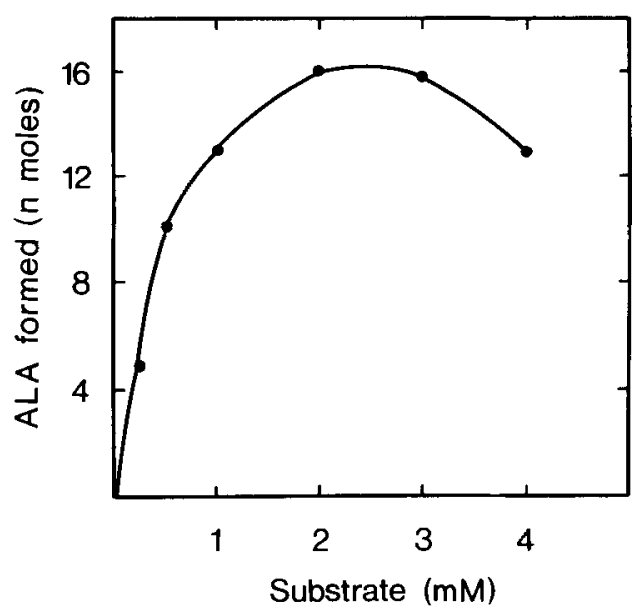

Figure 5. The effect of substrate concentration on glutamate-1-semialdehyde aminotransferase. Assay conditions are as given under Table I. ALA $=\delta$. aminolevulinate. glutamate- $\mathrm{U}-{ }^{14} \mathrm{C}$ involves a transamination step (8). The effect of several known inhibitors of transamination on the aminotransferase activity is given in Table III. The transaminase inhibitors aminooxyacetate $(20 \mathrm{mM})$, cycloserine $(20 \mathrm{mM})$ and D-penicillamine $(20 \mathrm{mM})$ inhibited glutamate-1-semialdehyde aminotransferase by 57,43 and $9 \%$ respectively. Glyoxylate inhibited the enzyme by $27 \%$. The $\delta$-aminolevulinate synthesis from L-glutamate- $\mathrm{U}-{ }^{14} \mathrm{C}$ in isolated plastids is inhibited by very low concentrations of $\beta$-hydroxyglutamate reaching $96 \%$ inhibition at $50 \mu \mathrm{M}(8)$. This compound at 1 $\mathrm{mM}$ concentration had, however, no effect on $\delta$-aminolevulinate synthesis from glutamate-1semialdehyde.

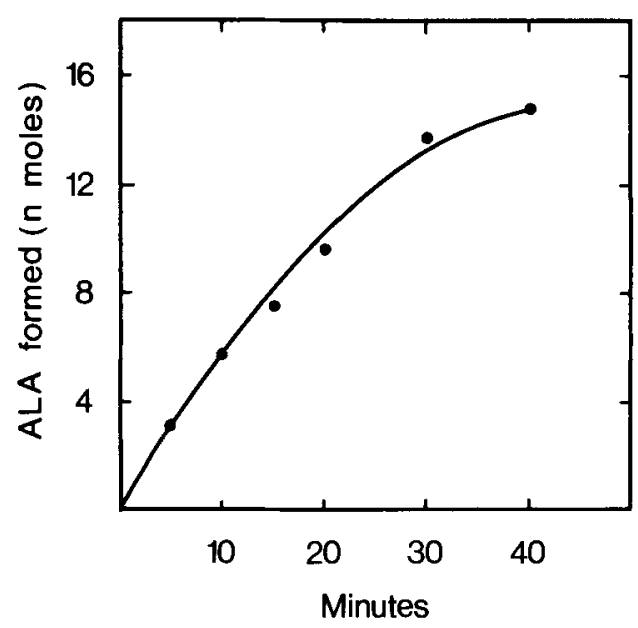

Figure 6. Time course of $\delta$-aminolevulinate formation by glutamate-1-semialdehyde aminotransferase. Assay conditions are given under Table I. ALA $=\delta$ aminolevulinate.

Pyridoxal phosphate at a concentration of 5 mM gave a $47 \%$ inhibition while pyridoxamine phosphate at the same concentration is stimulatory (Table III). The inhibitor of sulfhydryl containing enzymes, $\rho$-chloromercuribenzoate $(0.1 \mathrm{mM})$, inhibited the aminotransferase by $45 \%$ when added to the incubation mixture (Table III). In another experiment the enzyme was preincubated with 0.1 $\mathrm{m} M-\rho$-chloromercuribenzoate for 30 minutes at $22^{\circ} \mathrm{C}$ and $100 \%$ inhibition of activity occurred. 
Table III

Effects of inhibitors on $\delta$-aminolevulinate synthesis from glutamate 1-semialdehyde.

\begin{tabular}{|c|c|c|}
\hline Inhibitor & $\begin{array}{c}\text { Concentration } \\
\mathrm{mm}\end{array}$ & $\begin{array}{c}\delta \text {-aminolevulinate formation } \\
\% \text { of control }\end{array}$ \\
\hline \multirow{2}{*}{ Aminooxyacetate } & 1.0 & 89 \\
\hline & 20.0 & 43 \\
\hline \multirow{2}{*}{ D-Cycloserine } & 1.0 & 109 \\
\hline & 20.0 & 57 \\
\hline \multirow{2}{*}{ D-Penicillamine } & 1.0 & 82 \\
\hline & 20.0 & 91 \\
\hline \multirow[t]{2}{*}{ Glyoxylate } & 1.0 & 100 \\
\hline & 20.0 & 73 \\
\hline \multirow[t]{2}{*}{$\beta$-Hydroxyglutamate } & 0.1 & 104 \\
\hline & 1.0 & 100 \\
\hline \multirow{2}{*}{$\rho$-Chloromercuribenzoate } & 0.1 & 55 \\
\hline & 1.0 & 0 \\
\hline \multirow[t]{2}{*}{ Pyridoxal phosphate } & 0.025 & 95 \\
\hline & 5.0 & 53 \\
\hline Pyridoxamine phosphate & 5.0 & 111 \\
\hline
\end{tabular}

Assay conditions are given in section 2.6.

\section{3. $\Delta$-aminolevulinate synthesis from L-glutamate- $\mathrm{U}-{ }^{14} \mathrm{C}$ and glutamate- 1-semialdehyde}

Table IV compares glutamate-1-semialdehyde aminotransferase activity with $\delta$-aminolevulinate synthesizing activity from Lglutamate- $\mathrm{U}-{ }^{14} \mathrm{C}$ in different plastid types. Both activities were detected in soluble protein preparations from etioplasts, greening plastids and mature chloroplasts of barley. In greening plastids the two activities were respectively 5 to 20 fold higher than in etioplasts and mature chloroplasts when compared on a per mg protein basis.

\subsection{Fractionation of enzyme activites}

Fractionation of soluble proteins of greening barley plastids on a Biogel A 0.5 column gave a partial purification of the two enzymatic activities that synthesize $\delta$-aminolevulinate

\section{Table IV}

Comparision of $\boldsymbol{\delta}$-aminolewulinate synthesizing activities in etioplasts, greening chloroplasts and mature chloroplasts of barley.

\begin{tabular}{l|c|c}
\hline $\begin{array}{l}\text { Soluble protein extract } \\
\text { from }\end{array}$ & \multicolumn{2}{c}{$\delta$-aminolevulinate synthesis } \\
& \multicolumn{2}{c}{$\begin{array}{c}\text { from } \\
\text { glutamate- } \\
1 \text {-semialdehyde }\end{array}$} \\
\hline & L moles/mg protein & cpm fixed/mg protein \\
& 5.38 & 266 \\
l. Etioplasts & 28.6 & 11387 \\
2. Greening chloroplasts & 6.26 & 459 \\
3. Mature chloroplasts & & . \\
\hline
\end{tabular}

Plastids were isolated from 6 day old seedlings grown in darkness (for 1), 6 day old dark grown seedlings illuminated for 6 hours (for 2) and 6 day old seedlings grown under continuous illumination (for 3). Isolated plastids were disrupted by passing through a French pressure cell and soluble proteins were separated from membranes by ultracentrifugation as given under 2.4 . These soluble protein preparations were assayed directly for $\delta$. aminolevulinate formation. The assay conditions for the two activities are given under Table I and Figure 7 . 


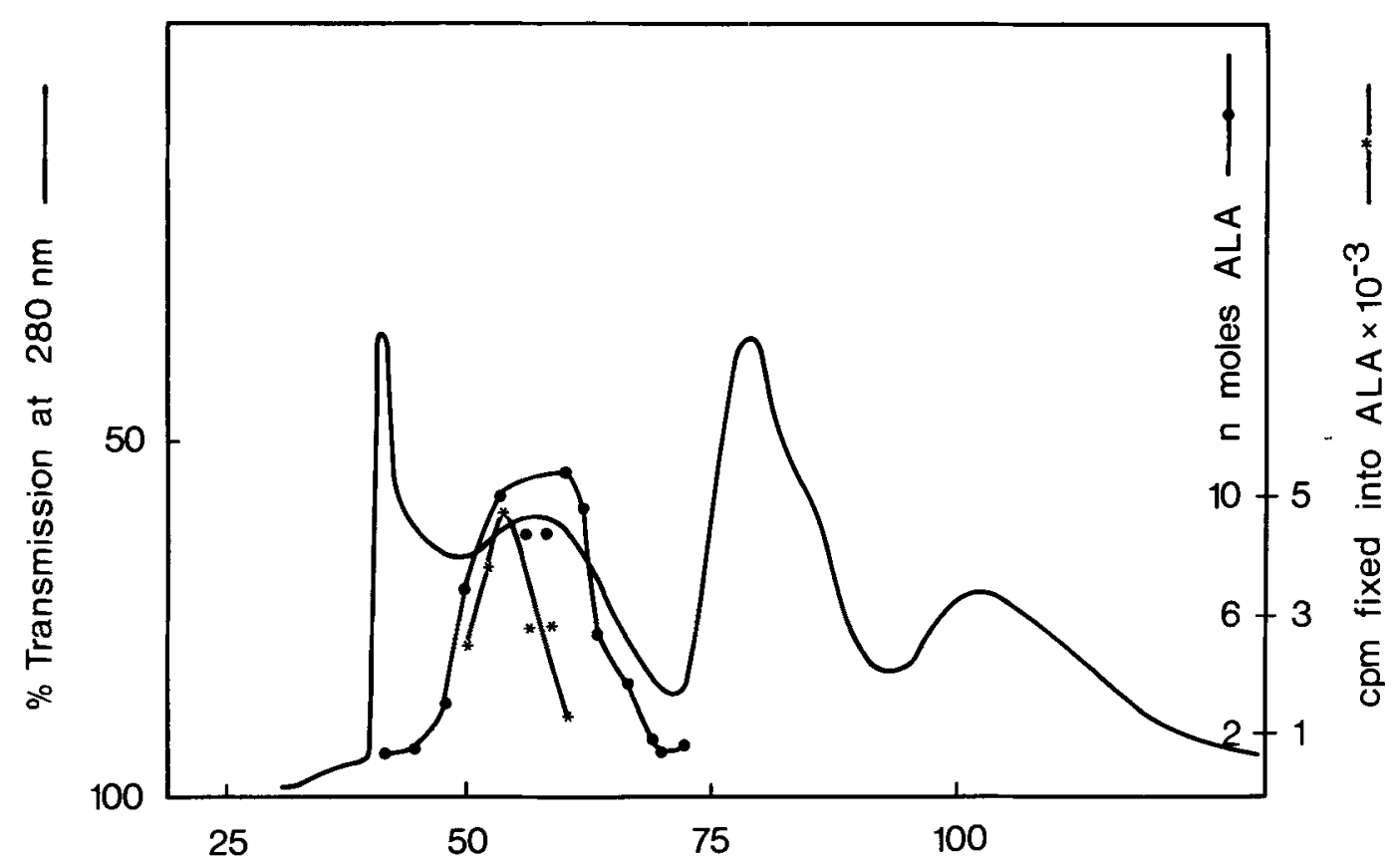

Fraction no.

Figure 7. Partial purification of $\boldsymbol{\delta}$-aminolevulinate synthesizing activities of greening barley chloroplasts.

Soluble proteins of greening barley chloroplasts were fractionated on a Biogel A 0.5 column $(2.5 \times 85 \mathrm{~cm})$ as given in 2.4. Glutamate-1-semialdehyde amniotransferase was assayed as in 2.6. The incubation mixture for Lglutamate- $\mathrm{U}-{ }^{14} \mathrm{C}$ incorporation into $\delta$-aminolevulinate contained in $1.2 \mathrm{ml}$ the following: $0.3 \mathrm{M}$-glycerol, $0.1 \mathrm{M}$ Tricine- $\mathrm{NaOH}, 1 \mathrm{~mm}$-dithiothreitol, $20 \mathrm{mM}-\mathrm{MgCl}_{2}, 0.5 \mathrm{mM}-\mathrm{ATP}, 0.25 \mathrm{mM}-\mathrm{NADPH}, 1.5 \mu \mathrm{Ci}$ L-glutamate-U- ${ }^{14} \mathrm{C}$ and $1 \mathrm{ml}$ of column fraction. The $\mathrm{pH}$ of the incubation mixture was 7.9. The mixture was incubated for 15 minutes at $22^{\circ} \mathrm{C}$ and assayed for incorporation of radioactivity into $\delta$-aminolevulinate (4). ALA $=\delta$-aminolevulinate.

(Figure 7). In the column eluate all the fractions which contained the ability to synthesize $\delta$ aminolevulinate from L-glutamate- $U-{ }^{14} \mathrm{C}$ also contained glutamate-1-semialdehyde aminotransferase activity. However the tail end fractions of the aminotransferase peak had no activity for the synthesis of $\delta$-aminolevulinate from L-glutamate-U- ${ }^{14} \mathrm{C}$. The results given in Figure 7 indicate that the two enzyme activities can be separated with glutamate-1-semialdehyde aminotransferase having a lower molecular weight than the enzyme that converts glutamate to $\delta$-aminolevulinate. Column fractions containing glutamate-1-semialdehyde aminotransferase could be stored frozen for several weeks without a noticeable loss of activity. In sharp contrast, the ability to convert L-glutamate- $\mathrm{U}-{ }^{14} \mathrm{C}$ into $\delta$-aminolevulinate was completely lost when the active fractions from the column were stored frozen for two days.

\section{DISCUSSION}

Soluble protein extracts of plastids isolated from greening barley leaves convert glutamate1-semialdehyde to $\delta$-aminolevulinate. The results presented in this paper show that this conversion is due to the presence in developing chloroplasts of an enzyme catalysing the transfer of the amino group from the C-2 position of glutamate-1-semialdehyde substrate to the $\mathrm{C}-1$ position. There are no previous reports on intramolecular transamination reactions in higher plants. It will be of interest to determine if the new enzyme is related to aminomutases (cf. 13) which function with a 
vitamin $B_{12}$ catalysed intramolecular transfer of an amino group. High concentrations of pyridoxal phosphate inhibit $\delta$-aminolevulinate synthesis from glutamate-1-semialdehyde by the partially purified enzyme. This could be due to the formation of a Schiff base between pyridoxal phosphate and a free lysine residue necessary for enzyme activity (2). Further experiments will have to be carried out in order to decide whether or not pyridoxal phosphate participates in the glutamate-1-semialdehyde aminotransferase reaction.

It is of interest to compare glutamate-1semialdehyde aminotransferase with the previously recognized activity synthesizing $\boldsymbol{\delta}$ aminolevulinate from L-glutamate (5). The soluble protein preparations previously shown to be capable of synthesizing $\delta$-aminolevulinate from L-glutamate-U- ${ }^{14} \mathrm{C}$ in the presence of ATP, NADPH and $\mathrm{Mg}^{2+}$ ions were also able to synthesize it from glutamate-1semialdehyde in the absence of added cofactors. Both enzymes are found with their highest specific activities in developing chloroplasts where active $\delta$-aminolevulinate synthesis occurs. Glutamate-1-semialdehyde has been considered as a possible intermediate in $\delta$-aminolevulinate synthesis (1). The present studies lend support to this route with glutamate- 1 -semialdehyde aminotransferase activity being a part reaction in the conversion of L-glutamate into $\delta$-aminolevulinate. We propose that the conversion of glutamate to $\delta$ aminolevulinate involves at least three enzymatic activities as illustrated in Figure 1. Glutamate is first phosphorylated by a kinase in the presence of ATP and $\mathrm{Mg}^{2+}$ to give glutamate-1-phosphate which is then reduced to glutamate-1-semialdehyde in the presence of NADPH by a dehydrogenase. The last step of $\boldsymbol{\delta}$-aminolevulinate synthesis is catalysed by glutamate-1-semialdehyde aminotransferase. The three enzymes may exist as a complex or separate proteins in the stroma of developing chloroplasts. The ability to carry out the overall reaction, the conversion of L-glutamate-U-14 C to $\delta$-aminolevulinate, is very unstable in partially purified preparations. This has hindered our attempts to purify this activity to homogeneity. In future attempts, purification of partial activities and reconstitution of the overall reaction should therefore be considered. This will help to determine which step is regulatory and also the mode of regulation of $\delta$-aminolevulinate synthesis in greening barley.

\section{ACKNOWLEDGEMENTS}

We thank Ms. Susanne Placing for skilful technical assistance and professor DITER vON WETTSTEIN for helpful discussions and critical reading of the manuscript. We also thank Ms. NinA RASMUSSEN for drawing the Figures, Ms. ANN-SOFI STEINHOLZ for photography and Ms. LENA KONGSRUD for typing the manuscript.

This work has been supported by grant GM 22051 of the USPHS, National Institutes of Health to professor D. vON WETTSTEIN.

\section{REFERENCES}

1. Beale, S. I., S. P. Gough \& S. Granick: Biosynthesis of $\delta$-aminolevulinic acid from intact carbon skeleton of glutamic acid in greening barley. Proc. Nat. Acad. Sci. USA. 72, 2719-2723 (1975)

2. Feeney, R. E., G. Blankenhorn \& H. B. F. DIXON: Carbonyl-amine reactions in protein chemistry. In: Advances in Protein Chemistry. C. B. Anfinsen, J. T. Edsall, F. M. Richards, eds., Academic Press, New York pp. 154-156 (1975)

3. Gassman, M., J. Pluscec \& L. Bogorad: $\boldsymbol{\delta}$ Aminolevulinic acid transaminase in Chlorella vulgaris. Plant Physiol 43, 1411-1414 (1968)

4. Gough, S. P. \& C. G. Kannangara: Synthesis of $\boldsymbol{\delta}$-aminolevulinic acid by isolated plastids. Carlsberg Res. Commun. 41, 183-190 (1976)

5. Gough, S. P. \& C. G. Kannangara: Synthesis of $\boldsymbol{\delta}$-aminolevulinate by a chloroplast stroma preparation from greening barley leaves. Carlsberg Res. Commun. 42, 459-464 (1977)

6. Harel, E. \& E. Meller: Synthesis of ${ }^{14} \mathrm{C} 5-$ aminolevulinic acid by cell free preparations from greening maize leaves. 4th International Congress on Photosynthesis. Abstract. 148 (1977)

7. HershberG, E. B. \& J. CAson: $\beta$-Napthaldehyde. Organic Synthesis, ed. E. C. Horning, John Wiley \& Sons, New York, Vol III, 626-633 (1955)

8. Kannangara, C. G. \& S. P. Gough: Synthesis of $\boldsymbol{\delta}$-aminolevulinc acid and chlorophyll by isolated chloroplasts. Carlsberg Res. Commun. 42, 441-457 (1977) 
9. Kannangara, C. G., S. P. Gough, B. Hansen, J. N. Rasmussen \& D. J. Simpson: A homogenizer with replaceable razor blades for bulk isolation of active barley plastids. Carlsberg Res. Commun. $42,431-440$ (1977)

10. Lowry, O. H., N. J. Rosenbrough, A. L. Farr \& R, J. RANDALL: Protein measurement with Folinphenol reagent. J. Biol. Chem. 193, 265-275 (195I)

11. Mauzerell, D. \& S. Granick: The occurence and accumulation of $\boldsymbol{\delta}$-aminolevulinic acid and porphobilinogen in urine. J. Biol. Chem. 219, 435-446 (1956)

12. MeISTER, A.: Preparation and properties of aminoacyl adenylates. Methods of Enzymology, ed. S. P. Colowick \& N. O. Kaplan, Vol VI, 751757 (1963)

13. Stadman, T. C.: B $_{12}$ Coenzyme dependent amino group migrations. The Enzymes, ed. P. D. Boyer, Vol. VI, 539-562 (1972)

14. Vebel, S.: Methods for the quantitative estimation of carbonyl compounds. The identification of Organic Compounds, G. E. C. Gad, Copenhagen, 151-167 (1961)

15. Weinstein, J. D. \& P. A. Castelfranco: Mgprotoporphyrin IX and $\delta$-aminolevulinic acid synthesis from glutamate in isolated greening chloroplasts. $\boldsymbol{\delta}$-aminolevulinic acid synthesis. Arch. Biochem. Biophys. 186, 376-382 (1978) 